\title{
Utz Richsner as Ideologue of the Schilling Uprising in Augsburg, 1524
}

\author{
ROBERT J. BAST
}

The University of Tennessee

The 1524 uprising of evangelical artisans in Augsburg on behalf of the Franciscan preacher Johann Schilling counts as a turning point of the Reformation movement in that city. Relying on chronicles, government reports, and interrogation records, previous scholarship-none better than Jörg Rogge'shas exposed the egalitarian theology and the social, economic, and political critique that united Schilling's supporters. Yet the source of their ideology has always been unclear, for Schilling left behind neither treatises nor sermon transcriptions. That lacuna can be filled in part by re-examining sources largely overlooked: the four pamphlets published in 1524 by the weaver Ulrich (Utz) Richsner. A contextual reading of those pamphlets suggests a close collaboration between Schilling and Richsner, and a much more central role for Richsner in the movement around Schilling than has yet been recognized.

La révolte en 1524 des artisans évangéliques d'Augsbourg pour le compte du prédicateur franciscain Johann Schilling est considérée comme un tournant dans le mouvement de réforme de cette ville. En se basant sur des chroniques, des rapports gouvernementaux et des minutes d'interrogatoires, la recherche - incluant les travaux inégalés de Jörg Rogge - a mis en lumière la théologie égalitaire ainsi que la critique sociale, économique et politique qui ont rassemblé les partisans de Schilling. Toutefois, les sources de cette pensée n'ont jamais été clarifiées, puisque Schilling n'a laissé ni écrits, ni transcriptions de sermons. Cette lacune peut être partiellement comblée en réexaminant des sources qui jusqu'à maintenant ont été négligées, c'est-à-dire les quatre libelles publiés en 1524 par le tisserand Ulrich (Utz) Richsner. Une lecture de ces textes dans leur contexte suggère une collaboration étroite entre Schilling et Richsner, ainsi qu'un rôle beaucoup plus important de Richsner dans le mouvement entourant le procès de Schilling, deux aspects méritant davantage notre attention.

"Ulrich Richsner wrote several pamphlets, earning the enmity of the Pharisees and great usurers and the ignorant, coarse guild masters, though they never read a word of them."

1. Research for this article was supported by a grant from the Jonathan Utley Faculty Research Fund from the University of Tennessee Department of History. For help and encouragement along the way I wish to thank Joel Van Amberg, Ann Tlusty, Hans-Jörg Künast, and the gracious and solicitous staff at the Staats- und Stadtsbibliothek Augsburg. All translations are my own, unless otherwise noted.

2. "Und der Ulrich Reichsner machet etliche buechlen, da waren im die phariseer und die grossen wuecherer und die unverstendigen, grobe viltzhuet, der keiner nie kein buochstaben gelesen hat, 
$\mathrm{I}^{\mathrm{n}}$ n the 1520s, the early Reformation movement took root in Augsburg at the sufferance of the city council, thanks to an evolving policy, tenuous in the extreme, that aimed for a moderate, Erasmian reform of the local church along lines that would satisfy the city's various constituents until the emperor would convene a national church council to decide all. To that end, Augsburg's magistrates embarked on what was in essence a cautious experiment in pluralism, permitting evangelical preachers to hold forth in three churches not under the bishop's control while the Catholic clergy dominated at the cathedral and its subsidiaries. ${ }^{3}$ In the event, the policy satisfied neither side, and tensions mounted until the morning of 6 August 1524 when some 1,800 artisans occupied Perlach Square, demanding that magistrates rescind the dismissal of the preacher Johann Schilling, whose populist evangelical preaching had fanned the flames of social, economic, and political discontent. ${ }^{4}$

Jörg Rogge's masterful and meticulous account of this uprising, composed from chronicles, government reports, and interrogation records, laid bare the conflicting ideologies that clashed that day, the artisans marshalling an egalitarian ethos of brotherly unity (brüderliche Einigkeit) against the magistrates' principle of paternalistic authority (väterliche Obrigkeit). ${ }^{5}$ Yet as with virtually every other account of the uprising, Rogge's rests on mere scraps of evidence-most of those culled from hostile sources-about what Schilling

veindt.” Georg Preu, “Die Chronik des Augsburg Malers Georg Preu des Älteren. 1512-1537,” Chroniken der deutschen Städte vom 14. bis 16. Jahrhundert (hereafter CDS), ed. Historischen Kommission bei der Bayerische Akademie der Wissenschaften, Bd. 29 (Leipzig, 1906), 25-26.

3. Andreas Gößner, Weltliche Kirchenhoheit und reichsstädtische Reformation. Die Augsburger Ratspolitik des "milten und mitleren weges" 1520-1534 (Berlin: Akademie Verlag, 1999), 34-52.

4. The episode appears in virtually every account of Augsburg's early Reformation. Unsurpassed is Jörg Rogge, Für den Gemeinen Nutzen. Politisches Handeln und Politikverständnis von Rat und Bürgerschaft in Augsburg im Spätmittelalter (Tübingen: Max Niemeyer Verlag, 1996), 246-72. See also Joel Van Amberg, A Real Presence: Religious and Social Dynamics of the Eucharistic Conflicts in Early Modern Augsburg, 1520-1530 (Leiden and Boston: Brill, 2012), 70f.; Allyson F. Creasman, Censorship and Civic Order in Reformation Germany, 1517-1648: "Printed Poison \& Evil Talk” (Burlington, VT: Ashgate, 2012), 78-87. Still indispensable is Friedrich Roth, Augsburgs Reformationsgeschichte, Bd. I (1517-1530) (Munich: Theodor Ackermann, 1901), 160-70; and Wilhelm Vogt, "Johann Schilling der Barfüsser-Mönch und der Aufstand in Augsburg im Jahre 1524," Zeitschrift des Historischen Vereins für Schwaben und Nëuburg, 6 (1879), 1-32, which, though almost comically tendentious, remains valuable for its lengthy transcriptions of archival sources.

5. Rogge, 276. 
actually preached. This has seemed an irremediable problem, for Schilling never committed himself to print, and no known contemporary transcriptions of his sermons have ever come to light. Surprisingly however, all previous scholarship has undervalued sources hiding in plain sight: four pamphlets written by the Augsburg weaver Ulrich (Utz) Richsner. ${ }^{6}$ Despite the fact that Richsner has long been known as one of Schilling's closest and most dedicated associates, we lack both concentrated studies of the weaver's work and critical editions of all but one of his pamphlets. ${ }^{7}$ It is not possible to fill that lacuna here, and what follows can be no more than a provisional and preliminary study, with two goals: first, to demonstrate close coordination between Richsner's pamphlets and Schilling's reform program, and second, to show that Richsner provided the sole published articulation of the central concepts evident in the ideology of the artisans' uprising.

6. These include (1) Ain hüpsch Gesprechbiechlin / von ainem Pfaffen und ainem Weber / die zuosamen kommen seind auff der straß waß sy fur red / frag / unnd antwort / gegen ainander gebraucht haben / des Euangeliums und anderer sachen halben (hereafter P-W); (2) Ain gesprech buechlin / von ainem Weber und ainem Kramer über das Buechlin Doctoris Matthei Kretz von der haimlichen Beycht / so er zuo Augspurg in unnser frawen Thüm geprediget hat (hereafter W-K; (3) Ayn außzug / auß der Cronicka der Baepst und iren gesatzen / wie gleychfoermig sy den gsatzen gots und leer der apostel seyen / zue vergleichen / auff das kürtzest und ainfaeltigest / zuosamengefugt, (hereafter Cronicka); (4) Ain schoene underweysung / wie und wir in Christo alle gebrueder und schwester seyen / dabey angezaigt nicht allain die weltlichen / wie sy es nennen / sondern auch die gaistlichen zuostraffen / wa sy anders in den leybe dessen haubt Christus ist woellen sein auff die geschrift gotes gegründt und daraus gezogen / zuo nutz allen die das goetlich wort lieben seindt (hereafter Unterweisung). This is the only of Richsner's works to appear in a modern critical edition: "Utz Rychsner, Eine schöne Unterweisung, daß wir in Christo alle Brüder und Schwestern sind," ed. Annerose Schneider, in Flugschriften der frühen Reformationsbewegung (1518-1524) Bd. I, ed. Adolf Laube et al. (Vaduz: Topos Verlag, 1983), 422-42. Richsner's printer in each case was Heinrich Steiner of Augsburg: see Martin Arnold, Handwerker als theologische Schriftsteller. Studien zu Flugschriften der frühen Reformation (1523-1525) (Göttingen: Vandenhoeck \& Ruprecht, 1990), 217-50; 217n1. The precise dating and order of publication remain controversial, with various sequences proposed. I have followed that suggested by Schneider, 439, as it stands here.

7. The best overview of Richsner's work may be found in Arnold (as in note 6). See also Paul A. Russell, Lay Theology in the Reformation: Popular Pamphleteers in Southwest Germany, 1521-1525 (Cambridge: Cambridge University Press, 1986), 121-27; Wolfram Wettges, Reformation und Propaganda: Studien zur Kommunikationen des Aufruhrs in süddeutschen Reichsstädten (Stuttgart: Klett-Cotta, 1978), 91-95. None of these, however, gives more than cursory attention to the relationship between Richsner and the Schilling uprising, and Russell's contribution is badly marred by facile and deprecating asides about the quality of Richsner's theology and religious values. 


\section{"I am a poor Weaver, as you can see. I am called Utz Richsner"}

Thus did Richsner introduce himself in his first pamphlet, a rousing defense of the Luther movement. ${ }^{8}$ What else we can know of him must come in part through context. As a weaver, he belonged to the largest guild in a city governed by guildsmen, and to the most restive. Augsburg rode a wave of prosperity into the sixteenth century, but it was generated by a new economy that rewarded the few at the expense of the many. Textile production had slipped in importance while international trade, mining operations, and the banking, credit, and currency exchange industries boomed. ${ }^{9}$ Corporate cartels helped to lock into place the economic dominance of Augsburg's elites: Fuggers, Welsers, Baumgartners, and a handful of others. ${ }^{10}$ Monopolies in the production and sale of ore and precious metals, sharp practices in the trade of foodstuffs, attempts to control the purchase and distribution of the raw materials essential to the guilds' rank and file-all these contributed to the new normal for Augsburg's working class: declining wages, rising prices, food shortages, and hard times. ${ }^{11}$ Disproportionate wealth had transformed politics as well, with guild republicanism slowly undermined by a shift of power to the small council, dominated by patricians and merchant-masters. In Augsburg, as elsewhere, this drift toward oligarchy found expression in the language of politics. Ruling elites drew from the vocabulary of landed lordship to designate themselves as Obrigkeiten, which made guildsmen like Richsner less citizens than subjects. ${ }^{12}$

8. "Ich bin ain armer Weber / jr solten mir es auch wol ansehen [...] Ich hayß Utz Richner." P-W, Eiiir. Both of Richsner's dialogues (his earliest works) associate the reform with Luther, though Luther's name is absent from the last two, which substitute variations on the term "evangelical."

9. Rogge, 102-05, and Philip Broadhead, "Guildsmen, Religious Reform and the Search for the Common Good: The Role of the Guilds in the Early Reformation in Augsburg," The History Journal 39.3 (1996): 577-97.

10. Mark Hälberlin, The Fuggers of Augsburg: Pursuing Wealth and Honor in Renaissance Germany (Charlottesville and London: University of Virginia Press, 2012). See especially chapter 3, "Jakob Fugger the Rich: The Making of an Enterprise, 1485-1525," 31-68.

11. Thomas A. Brady Jr., German Histories in the Age of Reformations, 1400-1650 (Cambridge: Cambridge University Press, 2009): 34-42, esp. 38-39, and Rogge, 102-05.

12. Broadhead, "Guildsmen, Religious Reform and the Search for the Common Good," 583. See also Erich Maschke, "Verfassung und soziale Kräfte in der deutschen Stadt des späten Mittelalters, vornehmlich in Oberdeutschland," Städte und Menschen. Beiträge zur Geschichte der Stadt, der Wirtschaft und Gesellschaft 1959-1977 (Wiesbaden: Franz Steiner, 1980), 170-274. 
Richsner himself felt the pinch of these times, amassing modest means between 1504 and 1508, only to slip back under the poverty line thereafter. The family moved frequently, always into the worse neighbourhoods on the city's margins. ${ }^{13}$ Though we cannot fix his age precisely, his family status tells us that he was likely past fifty, married, with a son and two grown daughters, one of whom had married a former monk who had fled the Carmelite monastery (an early site of Lutheran preaching). To Richsner's vexation, though his new sonin-law hoped to learn the weavers' trade, the guild masters were denying him entry on account of the "dishonourable" nature of the marriage. ${ }^{14}$

Where Richsner came by his education we do not know, yet he was not unusual. German schools flourished in Augsburg and artisans made use of them. Recent estimates gauge literacy at around 30 percent of the population, very broadly distributed. Augsburg's thriving market in vernacular publication testifies to this consumer base, and indeed depended on it. ${ }^{15}$ The city was unrivalled as a centre for the production of Flugschriften, the vernacular pamphlets that served as the most common form of written communication in, and on behalf of, the early Reformation. In Augsburg as nowhere else, these factors made it possible for Richsner to become an opinion shaper.

He first came to the attention of the authorities in late 1523 because of a contentious encounter in the Carmelite church of St. Anne, an early site of contested religious space. Its prior, Johann Frosch, had been a student in Wittenberg from 1514 to 1517 and had warmly hosted Luther in Augsburg during his 1518 appearance in the city. By the early 1520s, Frosch was preaching in a distinctly Lutheran manner and St. Anne's had become closely identified with the new movement. This was, to put it mildly, awkward, for the paint was barely dry on the magnificent family burial chapel in the west choir, completed only in 1521, which Jakob Fugger had financed at the staggering cost of 15,000 gulden;

13. For the relevant surviving tax records see Arnold, 221-22, 221n19.

14. Testimony of Hans Kag in Roth, 190.

15. The authority on this topic is Hans-Jörg Künast. See his "Getruckt zu Augsburg". Buchdruck und Buchhandel in Augsburg zwischen 1468 und 1555 (Tübingen: Niemeyer, 1997); see also his "Entwicklungslinien des Augsburger Buchdrucks von 1468 bis zum Augsburger Religionsfrieden von 1555," in Augsburg in der Frühen Neuzeit. Beiträge zu einem Forschungsprogramm, ed. Jochen Brüning and Friedrich Niewöhner (Berlin: Akademie, 1995), 227-39, and "Augsburg als Knotenpunkt des deutschen und europäischen Buchhandels (1480-1550)," in Brüning and Niewöhner, eds., 240-52. 
moreover, the Fuggers were fiercely loyal to the Catholic establishment. ${ }^{16}$ Under mounting pressure to silence the heterodox, Bishop Christoph von Stadion had begun to take action against "Lutheran" preachers, orchestrating the public arrest of the priest Caspar Adler, who was legally subject to the bishop's authority, and petitioning the city council to take action against Johann Frosch, who (as a monk) was not. But the magistrates had rebuffed the request, and thus the bishop could do no more than continue to compile evidence against the preacher. ${ }^{17}$

So it was that on October 22, congregants who had gathered in St. Anne's to hear Frosch preach noticed the suspicious presence of the bishop's beadle, Claus Hirschmann. Immediately after the sermon, the beadle was confronted by angry evangelicals, including Utz Richsner, who berated Hirschmann for his part in the arrest of Adler. The beadle replied that the bishop was by no means done purging the clergy, and that Richsner himself had better watch out. ${ }^{18}$ More hot words followed between Hirschmann and Christoph Herwart, a wealthy and influential patrician firmly aligned with the new theology. The beadle admitted that he had come to report on Frosch, at the behest of "my gracious lord [the bishop]," to which Herwart replied "We have one God and He is the Lord." Hirschman smoothly noted that Herwart himself wasn't above letting people address him as "my lord." Thereafter Herwart either did or didn't grab the beadle's finger, which Hirschman either was or wasn't wagging in Herwart's face (witness accounts varied). A young woman then forced her way into the crowd and said to the beadle that "she shits on him and his gracious lord" (not an uncommon vulgarity in this year; just a few weeks earlier, one of the lesser Fuggers had said publicly that "he shits in the Gospel"). Hirschmann called her a whore and told her to run along, to which she retorted that "all the whores are in the priests' houses." Another woman chimed in that "the bishop takes in 1,500 gulden a year from such women" (fines typically assessed on clergy living with concubines), which made the bishop "the greatest pimp in the land." Such was the tenor of ecumenical dialogue in $1523 .{ }^{19}$ In the end, in what was

16. Häberlin, 154-56.

17. Creasman, 79.

18. Arnold, 225.

19. Selections from the official inquiry that followed the incident at St. Anna's appear in Augsburg during the Reformation Era: An Anthology of Sources, ed. and trans. with intro. B. Ann Tlusty (Indianapolis: Hackett Publishing Company, 2012), 4-7. The Fugger vulgarity survives via Wilhelm Rem, who reported that on September 28, "da sagt Remundus Fugger offenlich vor den leutten, er schis in das 
probably an intentional affront to the bishop, the council had Hirschmann jailed for breach of the peace-a clear win for the evangelical party. ${ }^{20}$

\section{Johann Schilling}

The events of 1524 were the turning point for the Reformation in Augsburg-on that, everyone agreed. For the Benedictine chronicler, Clemens Sender, it was a year of grief and tragedy, ${ }^{21}$ while for Utz Richsner the year dawned in triumph. ${ }^{22}$ The catalyst for this change was the arrival in Augsburg of Johann Schilling, a Franciscan monk who rapidly emerged as the leading voice of the evangelical movement among the city's artisans. Such was the odd and tumultuous nature of Schilling's tenure that he produced no writings and left no disciples. Most of what we know of him is preserved in hostile sources, many of them compiled after the events narrated here, in an attempt to justify the conduct of a badly shaken city council. ${ }^{23}$ That said, Schilling appears to have been a man caught between two worlds. He was a member of the Franciscan order, still responding to the commands of his monastic superior though castigating Catholicism and preaching as an evangelical. He lodged in a monastery with hostile brothers

ewangelium" (Raymond Fugger said publicly, in front of people, that he shits in the gospel), in Cronica, CDS 25, 204. Rem says "in the Gospel," and though one suspects that the target of Fugger's ire was the evangelical faction rather than the biblical text, Georg Preu records the quote in exactly the same way: see CDS 29, 25.

20. Roth, 126 .

21. "Anno domini 1524 hat zů Augsburg die Lutherei fast zůgenommen und ketzerei überhandt, aller priesterschafft gram und aller gotzdienst verspott und vernicht [...]” (In the year of our Lord 1524, Lutheranism greatly increased and heresy took over, the priesthood was scorned and all worship mocked and destroyed). Sender, Chronik, CDS 29, 154.

22. "Pfaff. Was ist für geschray zuo Augsburg? Was halt man vom Luther regiert er noch mit seyner lere? Weber. O ye lenger ye fester / und als wenig man yetz mag laub unnd graß im erdtrich behalten / als wenig mag die sach undertrucktt werden" (Priest: What's all that outcry in Augsburg? What do people think of Luther? Does he still reign there with his doctrine? Weaver: More and more! As little as the earth can now hold leaves and grass, so little may his cause be suppressed). P-W, $\mathrm{A}^{\mathrm{v}}$.

23. The best accounts of Schilling's tenure in Augsburg are the extensive, insightful, and balanced accounts of Van Amberg, 43-82, and Rogge, 246-83. See also Philip Broadhead, "Popular Pressure for Reform in Augsburg, 1524-34," in Stadtbürgertum und Adel in der Reformation. Studien zur Sozialgeschichte der Reformation in England und Deutschland, ed. Wolfgang Mommsen (Stuttgart: Klett-Cotta, 1979), 80-87. Among the older literature, see Roth, 157-65, and Vogt, as in note 4, above. 
who continued to celebrate the traditional Roman rites that Schilling openly opposed. He dressed as a monk by day, though he grew out his tonsure and went out at night garbed as a layman. Reports of erratic behaviour followed Schilling to Augsburg from his previous posting and dogged him thereafter: drunkenness, fornication, fraternizing with a rough crowd, fomenting unrest. ${ }^{24}$ Such charges cannot have been entirely baseless, but they must be taken with caution, given the hostility of the sources, ${ }^{25}$ and they are difficult to reconcile with the devotion he inspired in members of his Augsburg congregation; for the poor artisans who made up the bulk of Schilling's following held him as a hero, a preacher of "good evangelical things from Holy Scripture," who did not shy from the gospel but led people to Christ. ${ }^{26}$

In the spring of 1524 (no records tell us more precisely when he arrived) Schilling was installed as Lesemeister in the Franciscan monastery. As such, his primary responsibilities would have been to teach theology within the chapter and to preach to the citizens who patronized the church. The former cannot have gone well. The new theology caused deep divisions among the brothers, and the chapter would dissolve in 1526 . But the preaching was an extraordinary success, if only for the evangelicals. Schilling adopted the lectio continua style, working verse by verse and chapter by chapter through the Gospel of Luke. Contemporaries tell us that the effect was extraordinary. The Franciscan began to outdraw all other preachers, as common folk-artisans and labourers in particular; "the mob," according to Schilling's critics-flocked from other parishes to hear his sermons, filling the cavernous Franciscan church, in the city's poorest district, which could hold upwards of two thousand. Though no direct record from these sermons survives, Joel Van Amberg has argued plausibly that Schilling chose his biblical text precisely because it addressed issues of immediacy to his working-class congregants. Luke's Gospel, "more than any other book in the New Testament, seeks to identify the cause of Jesus with the poor, and his mission with their mission. In Luke, God is [...] clearly

\section{Van Amberg, 61.}

25. See Sender, Chronik, CDS 29, 155-56. Various government officials compiled reports on the incident after their public humiliation on 6 August; these naturally put Schilling in the worst possible light. Selections from these reports, one written by the long-serving and influential syndic Konrad Peutinger, another perhaps by the patrician councilor Matthias Langenmantel, are transcribed in Vogt, 23-26.

26. Rem, Cronica, CDS 25, 204. See also the near-hagiographical remembrance of Schilling in later evangelical records: Vogt, 29. 
on the side of the poor and powerless." ${ }^{27}$ Schilling's critics found his preaching alarming and faulted his temerity in the way that he applied Scripture to civic life: "He criticized both clergy and magistrates [...] and preached as if all things should be held in common." ${ }^{28}$ To the magistrates, Schilling was perverting the very purpose of preaching, which they parsed, through the interests of oligarchs, as "instruction in Christian living, patience, and all due obedience."29

Behind the highly-charged language against or in support of Schilling's activities, we can detect a reform program composed of interrelated elements. The first was an attack on the old faith, its sacraments, rituals, teachings, and personnel; the second, a blistering social critique that took as its subject the gross economic inequality in Augsburg; the third, a mounting criticism of the city council for failing to hearken to the commons' demands for a thorough evangelical reformation; the fourth, an insistence on the principle of Christian equality, abolishing ancient distinctions that set clergy over laity and that elevated the rich, the politically powerful, and the noble above the common citizen. ${ }^{30}$ Running through all of these was a consistent egalitarianism, which Schilling and his supporters hoped to realize within their ideal, purified Christian community, where hierarchies would vanish in the light of the Gospel (though this was a partisan vision, dismissive of the wishes of Augsburg's Catholics, and predicated upon their conversion, suppression, or elimination). The most damning claim Schilling made, according to Augsburg's magistrates, was this one: "Where the council does not act, the commune must act." ${ }_{11}$ Schilling's sermons offended not simply because he denounced powerful people by name, but because the content of his sermons crossed a line, in the minds of his critics, between legitimate religious values (morality, patience, obedience) and subversion of the socio-economic status quo. ${ }^{32}$

\section{Van Amberg, 59.}

28. Vogt, 26; Rogge, 251.

29. Thus, for example, the anonymous report that claimed Schilling's sermons worked "mer zů frefel und Zereißung der liebe dann zůe underweisung christlichen thons, gedůlt und aller gehorsam dienstlich gewesen" (more to encouraging insolence and destroying love than to instruction in Christian behaviour, patience and all dutiful obedience). Rogge, 253.

30. See especially Van Amberg, 53-62, who argues persuasively that Schilling arrived in Augsburg with this agenda already in place.

31. The charge appears in the report of Peutinger, excerpted in Vogt, 22.

32. See Van Amberg, 56-57; Rogge, 275. 


\section{Schilling and Richsner: partners in reform}

At some point in 1524, Richsner shifted his allegiance from Frosch and the congregation of St. Anne's to Schilling and the Franciscan church. Thereafter he would become one of Schilling's known intimates, one of a small group of artisans who associated with the Franciscan after hours and away from the friary, where the time was passed drinking, discussing theology, grumbling about the slow pace of Augsburg's reform, and formulating plans on how to push it forward. ${ }^{33}$

Though none has suggested it until now, there is reason to suspect that Schilling had a hand in both Richsner's ongoing education and his publication program. This is not to question Richsner's theological competence, nor his literary gifts, both of which were considerable, though the latter often rough and earthy. His works contain enough personal reminiscences and passing observations on Augsburg society to dismiss any doubt that he was the primary author. And yet there are elements that suggest at least some collaboration with Schilling, as when Richsner appeals to Hugh of St. Victor, Bede, and Augustine on the proper understanding of penance, ${ }^{34}$ or rehearses the different renderings of St. Peter's name in Hebrew, Syriac, Greek, and German. ${ }^{35}$ Then there is the matter of his source material. Richsner makes regular use of several late-medieval chronicles of the popes. His most important source-one from which he quotes extensively, and often verbatim-is Johann Bämler's Chronik von allen Kaisern und Königen und Päpste, published in Augsburg in 1476 and twice shortly thereafter. ${ }^{36}$ These are beautiful, weighty volumes, engraved and tinted masterpieces of the early print industry. ${ }^{37}$ The question that naturally arises is where an impoverished weaver got access to a book or books that had

33. In addition to Richsner himself, other associates of Schilling included a glazier, Bartholomew Nussfelder, Franz Laminit, a purse-maker, the weaver Peter Scheppach, and the mason Hans Has. See Tlusty, 215-16.

34. W-M, Br.

35. Richsner, Unterweisung, 438, lines 4-8.

36. It was lightly revised to bring the papal register up to date and reissued by Augsburg printers Anton Sorg in 1480 and Johann Schönsperger in 1487. See Arnold, 223-24, who gives an abbreviated title for the work.

37. See Anton Sorg's 1480 edition, Incun. 1480.B2, in the Lessing J. Rosenwald Collection of the Library of Congress, available online: http://hdl.loc.gov/loc.rbc/Rosenwald.0077.1. 
been out of print for some forty years. The most likely answer is the library of the Franciscan monastery, courtesy of its Lesemeister.

The best direct evidence of coordination between Schilling and Richsner concerns the campaign to end the consecration of water and salt in the Franciscan church, a microcosm of Augsburg's uneasy experiment in Christian pluralism, for it alternated as the sacred space in which monks loyal to the old faith still celebrated their ancient rituals, and as the site of Schilling's heated evangelical sermons. Schilling found this intolerable, and had preached repeatedly for the abrogation of these rites to no effect. On the first Sunday of May, the topic came up again as Schilling gathered with friends over drinks at the home of the mason Hans Has. Richsner was there, together with a fellow weaver, Peter Scheppach, Bartholomew Nussfelder, a glazier, and another unidentified monk. Dark words were spoken as Schilling vented his frustration. Nussfelder ridiculed the notion of "holy water" and said that hed like to take the missal from the celebrant and throw it into the font. Egged on, the glazier promised to do so on the following Sunday. Schilling reportedly gave the plan his blessing. ${ }^{38}$

As it happened, the incident got out of hand. In what clearly had become an anticipated performance, Nussfelder was accompanied by many Schilling supporters, male and female, Richsner and his wife among them. It was the women who acted first, shouting down the monks, warning them to leave off the ritual blessings of water and salt. When the monks persisted, Nussfelder approached the celebrant and insisted that he speak German, not Latin. The monk refused, telling Nussfelder to go away and let the blessing continue. Nussfelder demanded the missal and warned the monk to "get out of here, for you are turning us away from Gospel truth that they preach to us every day. You're keeping us from it." With that, Nussfelder threw the book in the font. He was then joined by a purse-maker, Franz Laminit, who took the book out of the water and tried to tear it with his teeth. When he couldn't-it was parchment, not paper-he produced a knife and cut it to pieces. The crowd by that point was raucous, talking and yelling. A group of bold women-their presence mentioned in multiple accounts, as it made an impression-pressed forward to the font, shouting that "someone should throw the monk in the holy water too!" Amid this confusion, the weaver Peter Berringer cried out the 
words that probably sealed Schilling's fate in Augsburg: "Is a mayor greater than the commune?"39

These actions had consequences, some of them immediate. By midafternoon of that same day, authorities arrested those they identified as the ringleaders: Richsner, Nussfelder, Berringer, Laminit, and Sixt Saur, a bookkeeper. Under interrogation, Richsner played down his role. He had been standing in the back of the church with his young son, he explained, and couldn't see what was happening at the font. As to the meeting the previous week, Richsner claimed that he had gone to Has's house to speak with the mason on another matter; he hadn't paid attention to what Schilling was discussing with Nussfelder. None of the other prisoners implicated him more fully, and Richsner's story held. In the city, meanwhile, the streets were growing dangerous due to anger from the prisoners' supporters. Anxious magistrates strengthened the night watch and sent them out in armour. To mollify the crowd, Richsner and Saur were released after two days without further punishment, though they had earned the lasting enmity of important men in high office. ${ }^{40}$

Yet Richsner's role in this episode went much farther than he let on, a fact missed both by his interrogators and by all subsequent scholarship. The evidence comes from Richsner's Chronicle of the Popes and their Laws. Two consecutive passages stand out:

\footnotetext{
Pope Alexander [...] ordained that holy water and salt be consecrated every Sunday for the forgiveness of sins. Yet God spoke through the prophet Isaiah in the 43 chapter, "I alone am He who takes away your sin, so often as you have true contrition for it." But the Pope knew a much easier way than God, through water and salt. Thus people have taken up his law and commandment and hidden the word of God behind the door [... ${ }^{41}$
}

39. Van Amberg, 52 and note 30, citing the interrogation record of Hans Berringer on May 8 and 11. See also Rogge, 251f.; Arnold, 228; the contemporary chronicle of Georg Preu, who notes the initiative of the women, CDS 29, 25; the testimony of Nussfelder in Tlusty, 215-16.

40. Testimony of Richsner in Arnold, 228. On the unrest in the city and Richsner's mounting reputation as a troublemaker, see the chronicle of Preu, CDS 29, pp. 24-26.

41. "Alexander [...] hatt auch auffgesetzt / das weychwasser / und saltz zuo weyhen all sontag zuoabnemung der sünd / unnd got spricht durch den propheten Ysaie am 43 Capitel. Ich bin allain der / der dir deyn sünd vergybtt / so oft du ware rew darüber hast / Aber der Bapst Alexander hat vil ain nechnern weg gewuost durch das wasser unnd saltz wann durch got / darumb so helt man billich so 
Sixtus [...] established that women were not to touch any consecrated thing that pertained to the altar. This Pope must not have had the Holy Spirit if he thought so little of women as to regard them as unworthy to touch the consecrated things that belong to the altar. [...] And yet women are as worthy as men to receive and consume the sacrament of the altar. ${ }^{42}$

Though we cannot precisely establish the date of publication, the obvious conclusion is that Richsner's pamphlet was part of a coordinated effort between Schilling, Richsner, and a committed circle of lay men and women who came to a consensus (over time, and likely through meetings and conversations never documented) on specific goals-explicitly, to end the celebration of Catholic rituals in sacred space now claimed by the evangelicals; additionally, to assert in print what was already evident in practice: the right of women to participate in that sacred space. ${ }^{43}$

The bill came due for Schilling's partisans in the weeks that followed, for as Rogge has so perceptively shown, the words spoken by Berringer touched a particularly sensitive nerve among the magistrates of the small council, already on edge over Schilling's populist assertion that "Where the council does not act, the commune must act." The evangelicals had their supporters in city hall, but none of them could countenance an attack on the system that Augsburg's oligarchs had carefully built and tended since successfully subverting the guild

vill auff sein gesatz unnd bott / und zeücht das sein herfür / unnd setzt das wort gots hynder die thür." Chronicka Aiiiiv. See also the shorter, parallel passage in P-W, Diiv.

42. "Sixtus [...] satzt auf [...] das die wyber nichs geweychtes solten anrueren / das da zuo den altar gehoert. Hat aber nit diser Bapst auch den hayligen Gaist gehabt das er die weyber so leycht geachtet hat / als seyent sy nit wirdig das sy das geweycht an sollen rieren / des man zuo dem altar braucht [...] und sollen doch die weyb / wirdig sein des sacraments des altars zuo niessen / und entpfahen als wol als die mannen." Chronicka Aiiiiv. The passage ends with Richsner's ribald observation that consecrated priests obviously don't mind touching women, as can be proven by their offspring.

43. The episode with the bishop's beadle in 1523 demonstrates that women among Augsburg's evangelicals did not wait for permission from Richsner or Schilling to press the cause of reform. Both incidents suggest that we need to expand the very short list of cases counted among the examples of "collective action by women in the early Reformation": Tom Scott, "The Collective Response of Women to Early Reforming Preaching: Four Small Communities and their Preachers Compared," in Scott, The Early Reformation in Germany: Between Secular Impact and Radical Vision (Burlington, VT: Ashgate, 2013), 117-42, 117. Of course, Richsner's potentially transformative assertion had no appreciable effect on the roles permitted women in the emerging Protestant churches. 
revolution of 1378. They were Obrigkeiten now, on par with princely authority. The words of Schilling and Berringer, spoken publicly no less, before eager and angry working-class crowds, dangerously invoked an older age of communal autonomy and its chief political principle, that power is granted from below to civil servants who must answer for it. Something had to be done. Laminit was effectively sentenced to four weeks in the city prison, Nussfelder was banished for a year, while Berringer-who had done nothing more than to ruminate loudly on political science-was stripped of his citizenship and exiled for life. ${ }^{44}$

Other consequences developed more slowly. The tumult at the friary shocked not just loyalists of the old faith, but "respectable" Lutherans who began to distance themselves from "the mob," a rift that would deepen over time with long-term consequences for the city's fracturing evangelical movement. ${ }^{45}$ For Schilling's tenure in Augsburg, the affair was the beginning of the end. Prominent councillors began to work quietly and behind the scenes to rid themselves of the Franciscan. Aware of the volatility of Schilling's enormous following, the influential syndic and civic secretary Konrad Peutinger hit upon a simple method for getting rid of the monk without incurring the blame: have Schilling's superior recall him. The council thus wrote the Franciscan provincial general for southern Germany, laid out an account of Schilling's transgressions (now lost), and arranged for him to be summoned to Rothenburg. All was in place on August 3rd when a delegation from the small council called on Schilling, showed him the provincial's letter, and presented him with a fait accompli. He was finished in Augsburg, that much was clear, but if he left quietly, the city would provide him with a horse, a servant, and 20 gulden in travel money. Implied (perhaps spoken, though there is no record of it) was Schilling's perilous position. Away from Augsburg, without the protection of the council, and with his monastic superior now alerted to the "heretical" tenor of his evangelical preaching, Schilling's life was in danger. But horse, servant, and stipend gave him the opportunity to simply disappear. Schilling took the deal. $^{46}$ 


\section{The Schilling uprising}

The magistrates barely had time to congratulate themselves before their elegant solution unravelled. On the morning of August 6, as the small council convened in city hall, Schilling's evangelicals took to the streets. Hundreds of artisans began pouring into Perlach Square outside the council's chambers. Richsner was there, his weavers the most heavily represented of Augsburg's guildsmen, come to demand an accounting of their magistrates. The crowd chose a committee of a dozen to present their requests. Herwart, the patrician councillor who had defended Frosch against the bishop's beadle, emerged as an acceptable interlocutor. The opening statement of the artisans was peaceful: they wished to know why their preacher had been removed, and they wanted him back. If it was found that he had broken some law, then they would willingly accept his punishment, but if he was shown to be blameless in doctrine and conduct, then he should be allowed to return. They begged the council not to leave empty the pulpit at the Franciscan church, which served so many of the city's poor. ${ }^{47}$ The magistrates responded with their cover story: the council never intended to hinder the preaching of the Gospel; Schilling had been recalled for good reasons by his superior; they could not prevent his departure. However, to ensure the unabated preaching of the Gospel, until a suitable replacement could be found, the magistrates would provide an evangelical to serve as interim pastor: Urbanus Rhegius. ${ }^{48}$

If councillors expected the petitioners to be satisfied with this arrangement, they misread the mood. Though the citizens' committee seems to have accepted their offer, it did not pass muster: Herwart got no further than the name "Urbanus" when a deafening cry went up from the assembled artisans.

47. See Rogge, 256, and Van Amberg, 70, who both follow the anonymous account preserved in manuscript form under the title Beschreibung der Aufruer so sich Allhie Im Augsburg wegen eines Mönchs als mann Nach Christi geburt zelete 1524 Jar den anderen tag Augustii Erhoben, Evangelisches Wesensarchiv Augsburg Nr. 480, here at $11^{\mathrm{r}}-11^{\mathrm{v}}$. I am most grateful to Joel Van Amberg for graciously sharing with me his copy of this document. Though the manuscript as a whole has never been printed, excerpts were transcribed and appended to Vogt (as in note 4 above), 20-24.

48. Vogt, 22. Rhegius was a celebrated humanist, a former poet laureate, and had briefly held the endowed preachership at the Cathedral-with a handsome salary of 200 gulden per annum, seven or eight times what the average Augsburg artisan might earn-until his growing sympathy for the new theology prompted his ouster. He would later return as Lutheran preacher of St. Anna's, mocked by the poorer evangelicals as the "merchant's preacher": see Van Amberg, 27, 89, and 173; and Roth, 57-59. 
With a roar, the people demanded Schilling's return: "Give us the monk! We want the monk back, and no one else!" 49 Tempers flared as the crowd swelled and surged to perhaps $1,800 . .^{50}$ Some of their number occupied the steps of city hall while a few pushed their way into the building. To their shock and chagrin, Augsburg's oligarchs found themselves virtually besieged in their own chambers, their impotence exposed to the lifeless gaze of Emperor Maximilian, whose likeness graced the building's exterior. ${ }^{51}$ Forced to withdraw to the second story, the councillors were reduced to peering through the shutters and grimly taking down names. ${ }^{52}$ Among those spotted was Richsner, marked down not merely as a participant but as one especially insolent. ${ }^{53} \mathrm{~A}$ weaver, Peter Otter, shouted out what many suspected, that the council was lying about Schilling and intended to suppress the evangelical movement. Another weaver, Claus Daniels, called out that they would ask for the monk once more, then resort to force. ${ }^{54}$ Emboldened artisans began to shout abuse: the councillors were "fat scoundrels," "hypocrites," "enemies of the poor and of the commune." Some called for a showing of hands-a furrier threw both arms into the air and cried that if he could, he'd raise both feet too. A weaver shouted that "we have a majority!" Some called for the dismissal of councillor Anthony Bimmel, who, though an evangelical supporter and a member of the weaver's guild, was hated and mistrusted for complicity in Schilling's dismissal. The weaver Hans Pflam pleaded for fraternal unity_ "Let us all stick together like brothers!"55 Others practised fraternal correction, scolding the councillors as keepers of whores. ${ }^{56}$ Ideologies met and clashed that day in Perlach Square, and for several hours it seemed as if Schilling's program of communal brotherhood might win out against the authoritarian paternalism of Augsburg's oligarchs. But the crowd's moment passed. By mid-afternoon, "making a virtue out of a necessity," and

\section{Vogt, 22.}

50. This was Peutinger's estimate: Vogt, 21.

51. Pia Cuneo, Art and Politics in Early Modern Germany: Jörg Breu the Elder and the Fashioning of Political Identity ca. 1475-1536 (Leiden: Brill, 1998), 113.

52. Sender, CDS 23, p. 157.

53. Arnold, 230, citing the official report compiled by the magistrates.

54. Rogge, 259.

55. Rogge, 257.

56. “[...] erhalter der Hueren.” Rogge, 261. 
with as much dignity as they could muster, the councillors emerged to promise that Schilling would be back in his pulpit in three days, in time for his regular Tuesday morning sermon. The artisans expressed themselves content, though they did not disperse without extracting a grudging promise of amnesty from the magistrates. ${ }^{57}$

The aftermath was tense but anticlimactic. When Schilling missed his deadline by half a day, a large crowd of his angry supporters again raced toward Perlach Square and city hall. This time the magistrates were ready for them, the civic guard bolstered by mercenaries, the sun glinting off breastplates, helmets, pikes, halberds, battleaxes, muskets, and artillery pieces. ${ }^{58}$ These did not settle nerves, however, and the noble canons of the cathedral chapter fled the city. ${ }^{59}$ Jakob Fugger, their great lay patron, barricaded his shops, buried his money, and followed them. ${ }^{60}$ Tensions continued to run high for many days, but in the weeks that followed, the magistrates successfully reasserted their authority. Schilling, now under close scrutiny and perhaps bound by oath to moderate his preaching, ${ }^{61}$ was never able to rekindle his following; three months later he left the city for a second time, virtually unlamented. ${ }^{62}$ The council meanwhile issued a new proclamation on 12 August, curtailing unauthorized assembly and political speech. Henceforth, "all citizens, residents, visitors [...] men and women, old, young, rich or poor" were forbidden to meet or contract with each other, "in houses, gardens, on the streets or in other places inside or outside the city," or to engage in speech that threatened or could be understood to threaten the peace of the city and the authority of the council. ${ }^{63}$

Yet some defied this ordinance. Two weavers, Hans Kag and Hans Speiser, continued to meet, to fume, and to plot. What inspired them, in part, was a shocking attempt on Schilling's life in late August or early September. Reportedly, the monk had been sitting in front of an open window in the Franciscan friary

57. Roth, 163.

58. Details from the official government report in Vogt, 26-28.

59. Rem, CDS 25, 206.

60. Friedwart Uhland, Täufertum und Obrigkeit in Augsburg im 16. Jahrhundert (PhD dissertation, Eberhard-Karls-Universität, Tübingen, 1972), 48.

61. See note 75 below.

62. Roth, 169.

63. Transcription in Vogt, 17-18. 
when a shot rang out from an old foundry across the canal. The ball had missed Schilling by only a handbreadth. ${ }^{64}$ It was this that led Kag, Speiser, and likely others, to contemplate regime change, singling out magistrates to be voted out of office and drawing up a list of demands to press on the council. ${ }^{65}$ In the end they were betrayed, swept up in a series of arrests initiated by the magistrates for the contravention of the 12 August mandate against political activism. While the vast majority of suspects were released without penalty, the council settled on a small group believed to harbour political goals dangerous to Augsburg's status quo. Most of these were banished for life; the weavers Kag and Speiser, condemned to death. At dawn on the morning of 14 September, without the customary ringing of the city bell, they were taken to the execution grounds outside the city and decapitated. ${ }^{66}$

One intriguing question never yet answered is whether the attempt on Schilling's life really happened. Such a serious breach of the peace should have sparked at least a government inquiry, yet there is no record of one. And if the incident had happened with the knowledge and tacit consent of the magistrates-an extraordinary thought-we would expect to find mention of it by those chroniclers partial to the reform. Yet they too are silent. But a rumour can be as effective as the truth, and this one clearly pushed Schilling's supporters to action. The one thing that we can say about it with some certainty is where it began. Its source was Utz Richsner. ${ }^{67}$

64. Testimony of Hans Kag in Roth, 191.

65. For analysis of their demands see Rogge, $270 \mathrm{f}$.

66. Rogge, 268f.; Roth, 168.

67. Testimony of Hans Kag: "Was ine zu solhen reden bewegt, were die ursach, das er vom Ullin Richßner gehert, man het zu dem munich zu den Parfuessen in sein stuben mit einer bichs über den graben hinein aus einem gemalten hauß, darinn man vor zeiten bichßen gossen, geschossen, were der munich, der guardian und noch ein junger munich am tisch gesessen, were ein wenig lecht umb ein span gefelt, so were der schuß in die stuben geraten und der munich erschossen worden" (What provoked him to such words was the fact that he heard from Ulrich Richsner that someone had taken shot with a musket at the monk in his room at the Franciscan monastery, across the moat from a painted house where they used to cast armaments; the monk, the guardian and another young monk were sitting at table; if the shot hadn't barely missed, it would have gone into the room and killed the monk). Roth, 191. 


\section{Richsner's Unterweisung and the ideology of fraternity}

Based on analysis of the interrogation records and related government reports, Rogge argued that the artisans active in the Schilling uprising had found their political voice in religious principles. The demand for "brotherly unity" abolished social distinctions between elites and commoners, clergy and laity. The practice of "fraternal correction" restored the entire community to mutual accountability without regard for estate or status. These principles are assumed to have developed out of Schilling's preaching. ${ }^{6}$ Probably they did, yet they found their broadest public expression in the pamphlets of Richsner, to which we must now return.

In Richsner's earliest dialogue, Priest chides Weaver for condemning the sins of the clergy: "Judge not, lest ye be judged, for judgment belongs to God alone, and to no one else." ${ }^{69}$ The Weaver counters: "One shouldn't stay silent about everything. The prophets rebuked kings to their faces for their sins, as one reads often in the scriptures, and they had no regard for the fact that the kings were their rulers [Obrigkeiten]. ${ }^{\prime 70}$ Biblical examples follow: Susanna before the High Priests; Daniel to King Nebuchadnezzar; John the Baptist before Herod. Yet the Weaver recognizes that he's fighting a losing battle: "The proud can never bear reproof [...] when a big shot [grosser Hans], spiritual or secular, never does good, nevertheless he doesn't sin-oh no, it's the one who reproves him, or talks about it: that one's the greatest sinner. But those are your old tricks." ${ }^{11}$

The principle is clear: sin must be confronted wherever it is found, regardless of status. This point, parenthetical in Richsner's first pamphlet, is central to his last and most radical, which appears in a modern critical edition under the misleading title, Eine schöne Unterweisung, daß wir in Christo alle

68. Rogge, 257-58; 272-83, esp. 275.

69. "Ir solt nit urtaylen auff das ir nit geurtaylt werden / das ist / das des urtayl allain Got zuogehoert / und sonst nyemant." Biiv.

70. : "[...] man soll nit gar zuo allen sachen schweygen / synd doch die propheten / den künigen under ir angesicht gestanden und hand sy gestrafft umb ir sünd / als man vil in der geschrifft find / und hand auch nit angesehen das sy ir oeberkayt seyendt gewesen." Biir.

71. "[...] aber die hoffart hat nye kayn straff muegen leyden [...] wenn ain grosser hans gaystlich oder weltlich nymmer nichts guets thuot / so thuot er doch kain sünd / aber woelcher darumb strafft / oder es von im sagt / der thuot die groesten sünd / aber es ist eüwer alter brauch." Biiiv. 
Brüder und Schwestern sind (A lovely lesson that we are all brothers and sisters in Christ). It is the subtitle, however, that signals Richsner's main purpose: to assert the right of fraternal correction over both the laity and the clergy. ${ }^{72}$ But more has changed than the matter of emphasis. Richsner's early dialogues radiated confidence in the ultimate triumph of the evangelical movement. By contrast, in tone and content the Unterweisung is dark, combative, and apocalyptic. $^{73}$ The difference surely owes much to the collapse of the movement around Schilling. Though it has been impossible to establish a precise date of publication, internal evidence suggests that it was written after 3 August and the de facto expulsion of Schilling from Augsburg. Richsner rages against the "High Priests and Prelates of Antichrist" who persecute preachers of the true word of God: "They arrest them, burn them, behead them or drive them from one land to another, and forbid them under oath to preach the Gospel."74 Allowing for some rhetorical excess, the elements of this complaint reflect Schilling's treatment by the authorities. ${ }^{75}$ The terminus ad quem is certainly the execution of Richsner's associates, the weavers Kag and Speiser, on 15 September, for the pamphlet closes with the expectation of a coming wave of

72. See Schneider's edition in Laube et al., Flugschriften I, 422-42 (though the full title is reproduced in the notes on p. 439). The title page of the original 1524 edition reads "Ain schoene Underweysung / wie und wir in Christo all gebrueder und schwester seyen / dabey angezaigt nicht allain die weltlichen / sonder auch die gaistlichen zuostraffen / wa sy anders in den leybe dessen haubt Christus ist woellen sein auff die geschrift gotes gegründt und darauß gezogen / zuo nutz alln die das goetlich wort lieben seindt" (A lovely lesson how, and that, we are all brothers and sisters in Christ. Also shown that we are to correct not only the so-called secular estate but also the clergy, if they want to be something other than members of the one body whose head is Christ. Grounded and drawn from the Word of God, for the benefit of all those who love God's Word; emphasis mine).

73. See especially Richsner, Unterweisung, 438, lines 37-43, which envision a coming persecution under the revivified Annas, Caiaphus, Herod, and Pilate.

74. "Also gond yetz unnsere oeberste priester unnd endtchristische prelaten umb mit denen, woelche sich fleyssen, das wort Gottes lautter und klar zuo predigen nach dem befelch Christi: Solche fahet man, verbrennet sy, koepffet sie, oder aber vertreybt sie von ainem land ins ander und verbeüt inen bey dem ayd, das evangelium zuo sagen.” Richsner, Unterweisung, 426, 18-23.

75. The passage may even help explain why Schilling's return was so anticlimactic: he never recaptured the devotion of the artisans, attendance at his sermons declined, and he left of his own volition in November. The assumption has always been that Schilling was restrained by the knowledge that the council had its eye on him (Roth, 169), but it may well be that the magistrates formally required him, under oath, to moderate his preaching-something that his followers would surely have seen as a betrayal. 
martyrdom that has not yet begun. ${ }^{76}$ In short, Richsner's pamphlet gets us very close to the events and the ideas behind the uprising in which he himself was identified as a ringleader.

The Unterweisung opens with a defiant declaration of equality against the clergy: "They don't want to be sisters and brothers with us, but better than us. And they say that they have authority to correct [straffen] us, and we have none over them." ${ }^{\prime 7}$ To the contrary, Richsner cites the language of Jesus and the apostles, who called God "Father" and addressed believers as "dear brother" and "dear sister." ${ }^{8}$ This status is in fact evident already from the moment of creation: "We are all brothers and sisters through Adam and Eve, by nature and also through the Spirit. For we were all created of the same earth, by the same God and Spirit. If anyone is made from a better substance or spirit, then he may gladly teach me otherwise." 79

From this principle of fundamental equality, Richsner moves to his second point: if we are all brothers and sisters in Christ, "then we all have power and authority to correct [straffen] each other whenever anyone sees someone sin against God and his neighbor." ${ }^{\text {" }}$ As proof, Richsner quotes the locus classicus on "fraternal correction": "For as Christ says in Matthew 18, "If your brother sins, reprove [Straff] him alone. If he won't accept it, take two or three with

76. "Und ich glaub, das es noch nit hab recht angefangen, unnser durchaechtung, wann ich mach mir dise rechnung Wann sy werden sehen, das sy weder mit warer rechter heiliger geschrifft die sach mügen umstossen, noch mit andern helen boeßn lüsten hinder sich tryben, so werden sy sich mit gewalt underston, das kindlin zuo toedten" (And I believe that our persecution has scarcely begun, for I reckon thus: when they see that they can neither subvert the cause with true holy scripture, nor divert it by other evil means, then they will determine to kill the little children with force). Richsner, Unterweisung, 438, 39-43. The allusion is to Herod and the slaughter of the innocents, Matt. 2:16-18.

77. "Item, sy woellen auch nit schwester und bruoder mit uns, sondern besser dan wir sein und sagent, sy haben gewalt uns zuo straffen und wir sy nit.” Richsner, Unterweisung, 422, 21-23.

78. Richsner, Unterweisung, 422, 37-423, 17.

79. "Unnd auß disen unnd andern sprüchen [...] ist gnuogsamlich bewert, das wir nach Adam und Heva natürlich bruoder und schwester sein, und nach dem geyst deßgleychen, wann ye von ainer erden, von ainem Got und gayst. Woelcher aber von ainer bessern substanz oder bessern gayst ist, den will ich mich geren ain andern weysen lassen.” Richsner, Unterweisung, 423, 19-23.

80. "Nun zuo dem andern: So wir dann alle schwester und bruoder seyen durch Christum und in Christo, so muossen [...] das auch nachgeben, das wir alle macht und gewalt haben, ye aines das ander zuo straffen, so es sicht daz jhener sündiget wider Got und sein naechsten." Richsner, Unterweisung, $423,39-424,1$. 
you. If he still scorns you, denounce him before the congregation [Gemaine] or church [Kirche]." ${ }^{1}$

On closer inspection, however, what appears to be a quote is instead a paraphrase. Richsner has dropped two words from the biblical passage: "against you." ${ }^{12}$ We could posit a simple oversight here, except that in an earlier dialogue Richsner quoted the passage faithfully: "Wann dein bruoder wider dich sündet." ${ }^{83}$ The elision is consequential. Matthew's Gospel imagines a conflict between two believers, a personal affront directly received. Richsner's makes the personal general, authorizing everyone to police sin wherever it is seen.

Yet the radical nature of Richsner's lesson only becomes clear when we ask what precisely he means by straffen. For the vernacular noun carries a wide range of meanings, from the benign and pedagogical to the punitive and corporal: to correct or rebuke, certainly, but also to discipline and punish (Augsburg's government, as did most others, recorded judicial punishments in a log called the Strafbuch). Richsner's meaning tends toward the latter, as demonstrated by a host of examples he draws from the New and Old Testaments (in that order), which provide biblical precedent for everything from harsh words to execution. Thus we read that Christ drove the moneychangers out of the Temple (Richsner: "would that it happened more often!"). ${ }^{84}$ Christ called those who falsify God's word "fools" and "a corrupt generation." Christ said it would be better for such people to be drowned in the sea with a millstone around their necks (Richsner: "but where would we find enough millstones?"). ${ }^{85}$ Christ called them children of the Devil, thieves, and murderers. ${ }^{86}$ Stephen, the first martyr of Acts, called them traitors, murderers, breakers of the Law of God. St. Peter struck down Ananias and his wife for trying to deceive the Holy Spirit (Richsner: "Oh that St.

81. "Wann also spricht Christus, Mathei am XVIII: Sündiget deyn bruoder, so straff in allain. Nympt er es aber nit an, nymm noch zwen zuo dir. Verachtet ers abermals, so verklage inen vor der gemain oder kirchen etc." Richsner, Unterweisung, 424, 1-4.

82. See Matthew 18:15.

83. W-M Aii ${ }^{\mathrm{v}}$-Aiii ${ }^{\mathrm{r}}$ (emphasis mine).

84. Richsner, Unterweisung, 424, 17-23, with his contemporary aside "Ich acht shier darfuer, es sol bald mere geschehen," at 20-21.

85. Richsner, Unterweisung, 424, 23-28; "Aber wa wolt man yetz mülstain gnuog finden, damytt man sie ertrencken moecht", 27-28.

86. Richsner, Unterweisung, 30-38. 
Peter were here among us, for many of those scoundrels need to die, especially the one who thinks he is St. Peter"). ${ }^{87}$

As Richsner shifts to the Old Testament, he begins by asserting that it remains binding for contemporary practice (breaking here with Luther, as it happens): "Now however I will also demonstrate what God has instructed us to do through Moses and the prophets, how we are to correct [Straff] those who want to reject the true Word of God in favour of their dreams and devilish ideas." ${ }^{\text {"T }}$ The examples and rhetoric turn increasingly violent, though with some colourful idiosyncrasies: when Moses spied an Egyptian oppressing the Hebrews, says Richsner, he killed him "auß goetlicher und bruederlicher lieb"- "out of godly and brotherly love." ${ }^{89}$ A long section devoted to Deuteronomy 13 gives Richsner the opportunity to equate the alleged moral, theological, and liturgical failures of his contemporaries with the idolatry and cultic transgressions of the ancient Hebrews, the punishment for which was death: "Moses said 'Every man is to slay the leaders of the people [haubtleutt] who have pledged themselves to false gods." ${ }^{\prime 90}$ But the final word in this section is given to Jeremiah: "God the Lord says 'Cursed be he who holds back his weapons from bloodshed." 91

Remarkably, Richsner acknowledges the political risk he is running: "There is much more that could be said and written here, but someone would say that it will lead to unrest [auffruor], even though it is the word of God." ${ }^{\prime 2}$ And yet, as if he cannot help himself, he continues. A rough retelling of Numbers 25 provides guidelines for the policing of sexual immorality. In Richsner's version,

87. "O, wie ist es so not, das Sant Peter yetz nit bey unns sey, wann es muosten yetz ir vil gaechlingenn sterben unnd am maysten die, woelche Sant Peter selbs woellent sein." Richsner, Unterweisung, 424, $29-425,6$.

88. "Ich will nu aber auch anzaygen, was unns Got gehayssen hat durch Mosen unnd die andern propheten, wie wir uns halten sollen mit der straff gegen dennen, woelche unns von dem wort Gottes woellent abweysen auff ire truom und teufelische eyngebung." Richsner, Unterweisung, 425, 14-18. On this disjuncture between Richsner's theology and Luther's, see Arnold, 250.

89. Exodus 2:11-12, explicated in Richsner, Unterweisung, 426, 4-6.

90. "Item Moses sprach: Ain yetlicher man erwürge seyn haubtleuett, woelliche sich dem Baal und Beor underworffen haben." Richsner, Unterweisung, 426, 38-40.

91. "Jheremie am 48. Capitel Spricht gott der herr / Verfluocht is der woelcher da weret seynen waffen / von des selben pluot." Richsner, Unterweisung, 426, 6-7.

92. "Nun es waere vil Darvon zuo reden unnd zuo schreyben, aber man wurd sprechen, es diente zur auffruor, wie wol es die wort Gottes seynd." Richsner, Unterweisung, 426, 33-34. 
the righteous Phineas enters a brothel to slay a couple caught in flagrante dilecto, thereby averting the wrath of God. The section concludes, again, with a contemporary application that drives home the scope of Richsner's lessons on fraternal correction:

From such passages may every pious Christian know well in his heart and mind how he is to act toward his brother, if he speaks, teaches or acts contrary to God and his holy word, and what God has commanded, not forbidden him to do, to discipline [straffen] his brother, out of zeal for the honor of God, and not at all for our own purposes. ${ }^{93}$

If Richsner meant the Unterweisung to serve as a blueprint for a civic moral cleansing, he would have been disappointed. Augsburg's own brothels continued to conduct a brisk trade into the next decade (though they would be closed, with mixed success, in 1532 during the temporary political ascendancy of local Protestants). ${ }^{94}$ Yet we should not overlook Richsner's accomplishment, for he articulated an ideology, grounded in Scripture, that redefined relationships in Augsburg to the advantage of its disenfranchised commons. By nature and by grace, all are brothers and sisters in Christ; as brothers and sisters, permittedcommanded! - to "correct" one another's sins. At the very heart of the rising of 1524 was the insistence that the Gospel could not be confined to "instruction in Christian living, patience, and all due obedience"; that it had to reach out from the pulpit and into Augsburg's social structures; that its principles subverted hierarchies of wealth and status; and that politics and economics were not distinct from religion but must be subsumed under it. These principles gave the artisans who rose in support of Schilling the very thing that law and tradition had denied them for generations: a system by which to call to account both clergy and magistrates. It is likely that Richsner's Unterweisung helps to explain the expressions of fraternal solidarity recorded on 6 August, and likelier still that it emboldened some to confront their superiors. Hans Kag, executed as a

93. "Auß solchen sprüchen mag ain yetlicher frummer Christ in seinem hertzen und gemuot wol ermessen, wie er sich halten soll gegen seynem bruoder, in dem so er redet, leeret, oder thuot wider Got und seyn hayligs wort, und was im Got gebotten und nit verboten hat, solliche zuo straffen und zu eyffern umd der eere Gottes willen, und garnicht von unsert willen.” Richsner, Unterweisung, 427, 14-18.

94. Lyndal Roper, The Holy Household: Women and Morals in Reformation Augsburg (Oxford: Clarendon Press, 1989), esp. 89-131. 
political agitator after the event, would admit during his interrogation that he had intended "to reprove mayor George Vetter in a good-hearted and brotherly manner to put away his mistress." ${ }^{95}$ And Kag named Richsner three separate times as a source of inspiration. ${ }^{96}$

Many questions about Richsner remain unanswered. Not least of these is the question of his fate. Friedrich Roth claimed in passing that Richsner probably died in 1525, as he was still on the tax role in that year. ${ }^{97}$ This seems highly unlikely. It is inconceivable that Richsner would have been left unmolested despite having been arrested in May for the disturbance at the friary, singled out weeks later as an insolent instigator of the Schilling uprising, recognized as the author of inflammatory pamphlets and named by Kag as a source of inspiration for the political agitation that continued in defiance of the 12 August mandate. Yet there is no record that Richsner was questioned, or even sought. The best guess is that he fled the city at the news of Kag and Speiser's arrest. Further research is needed to tell us more about the degree of coordination between Richsner and Schilling, the programmatic nature of the weaver's publications, and the extent of his connections to the most politically ambitious of his fellow guildsmen, for he and Schilling appear to have continued to agitate for regime change in Augsburg (by ballots, not blades, despite Richsner's violent rhetoric) right up to the arrest of his associates. ${ }^{98}$ What we have seen however should demonstrate the fruitfulness of a return to the early Reformation, rich in those moments that Tom Scott has singled out for the "astonishing mixture of radical religious disenchantment and straightforward thuggery" that took place as common people found their voice in the Gospel—as they understood it. ${ }^{99}$

95. "Er het auf ein tag [...] meinen burgermeister herren Georigin Vetter zu dem Stessinger therlin herein sehen geen und willens gehabt, ine zu straffen guetlich und bruederlich, das er seiner diernen muessig steen solt." The full transcript of Kag's interrogation is published in Roth, 190-95, 192.

96. Roth, 190 and 191.

97. Roth, 149n99.

98. See Van Amberg, 75, and the testimony of Hans Kag, as in note 92 above.

99. Scott, 30. 
